American Journal of Environmental Sciences 8 (3): 248-252, 2012

ISSN 1553-345X

(C) 2012 Science Publications

\title{
Threat of the Health Quality of Garden Produces Linked to Pollution by Toxic Metals on Some Gardening Sites of Benin
}

\author{
${ }^{1}$ Koumolou Luc, ${ }^{2}$ Edorh A. Patrick, ${ }^{1}$ Agbandji Lucien, \\ ${ }^{1}$ Hounkpatin S. Armelle and ${ }^{1}$ Elegbede Bernadin \\ ${ }^{1}$ Centre Interfacultaire de Formation et de Recherche en \\ Environnement pour le Developpement Durable, \\ Laboratoire de Toxicologie et de Sante Environnementale, \\ Universite d'Abomey-Calavi, 03 BP 1463, Jericho, Cotonou, Benin \\ ${ }^{2}$ Departement de Biochimie et de Biologie Cellulaire, \\ Faculte des Sciences et Techniques, \\ Universite d'Abomey-Calavi, 01 BP 526 Cotonou, Benin
}

\begin{abstract}
Problem statement: Water and soil are vital resources used in agriculture. Current data establish a link between the pollution of soil, water and public health. For this reason, this study attempted to establish a link between the level of pollution of garden sites in lead $(\mathrm{Pb})$, Cadmium $(\mathrm{Cd})$ and Arsenic (As) and the health quality of vegetables grown there, through the quality of soil and of the irrigation water. Approach: Composite samples of vegetables, irrigation water and soil taken in the same periods at two garden sites in the city of Cotonou and another one in the village of Aplahoue, were analyzed for $\mathrm{Pb}, \mathrm{Cd}$ and $\mathrm{As}$ by atomic absorption spectrophotometer. The amounts (average \pm $\mathrm{SD})$ have been compared by the statistical Student $\mathrm{p}$ test $(\mathrm{T}>\mathrm{t})=0.05$. Results: The results show that all the vegetables grown on the three sites are differently contaminated with $\mathrm{Pb}, \mathrm{Cd}$ and $\mathrm{As}$, as well as their irrigation water and the soil. However, the link attempted to be established between pollution of soil, irrigation water and quality of vegetables, could not be obvious, it has been discussed. Soil pollution with toxic metals seems to be of minor importance and does not directly influence the contamination of vegetables Conversely to soil pollution, the levels of contamination of irrigation water by trace metals ( $\mathrm{Cd}$ and $\mathrm{As}$ ) are much closer to that of vegetables, apart $\mathrm{Pb}$. However, the high urban and atmospheric pressures in Cotonou have significantly influenced the contamination. For, it is in Aplahoue, farming environment, that the lowest amounts of metals in water and in the vegetables have been recorded. Conclusion/Recommendations: There is a risk of contamination in the food chain by heavy metals whose consumption through these gardening products could cause public health problems. Thus, the adoption of reasonable behavior and the development of new technologies are needed to associate food security, economic development, the preservation of the environment and public health.
\end{abstract}

Key words: Toxic metals, soil pollution, vegetable quality, lowest amounts, garden produces, garbage dumps, toxic metals, absorption spectrophotometer

\section{INTRODUCTION}

Market garden produces are sought to address micronutrient, vitamin and protein deficiencies in Africa where food rations is mainly consisted of grain (Gnandi et al., 2008). With the economic crisis in Cotonou Benin, there has been an increase in the number of gardens as well as the increase of the cultivated areas (Assogba and Miguel, 1999). Most of the plots are scattered in cities, as the case of Cotonou. In these cities, many of the gardens are either on old garbage dumps or located near swamps, which are for most of them, areas of dumping of all kinds (Mougeot, 2000). It is not rare to find in these garbage, used batteries, paint pots, oil, crap metals, drugs and laboratory reagents. All these products are known to be direct or indirect emitting sources of toxic metals. In this environment, there is no guarantee about the

Corresponding Author: Koumolou Luc, Centre Interfacultaire de Formation et de Recherche en Environnement pour le Developpement Durable, Laboratoire de Toxicologie et de Sante Environnementale, Universite d'Abomey-Calavi, 03 BP 1463, Jericho, Cotonou, Benin 
sanitary quality of the harvested products. However, there exist some gardening sites in semi-rural regions that appear to be less polluted, such as the site of Aplahoue. The purpose of this current work is then to try to establish a direct link between the pollution of a garden site and the sanitary quality of the vegetables that are cultivated there in order to make an evaluation of the environmental health risk. The site of Aplahoue, apparently less subject to population pressure is taken as comparison with the gardening sites of the city of Cotonou.

\section{MATERIALS AND METHODS}

Study area: The two sites in Cotonou, Godomey and Houeyiho are far about $150 \mathrm{~km}$ from the Aplahoue site. Houeyiho site, 15 hectares in area, is located in the heart of the city, in a fenced enclosure, which is less affected by population activities. It is the most important site in Cotonou where market produces gardening is permanent and organized with a compost production unit from the garbage collected. Inside the site are small shallows that are used for the watering of the vegetables. Conversely, gardening on the Godomey site is intermittent and the site is located on a flood plain, a swamp site having on its edge a pile of garbage of all kinds. Aplahoue site is a large crop field where irrigation water comes from a small river that runs through fields of cotton and food crops.

Processing and analysis: Composite samples of soil and irrigation water have been taken as well as eight different species of vegetables: Amaranthus hybridus (amaranth), Daucus carota (carrot), Lactuca sativa (lettuce), Spinacia oleracea (spinach), Allium cepa (green onion), Brassica oleracea (cabbage), Corchorus olitorius (fiddle), Salanum macrocarpum (nightshade).

All the samples have undergone the necessary treatment before heavy metals analysis by electrothermal atomic absorption spectrophotometer according to the method described in (Anane et al., 1995; Vaidya and Rantala, 1996).

Statistical tests: Results are presented in tables as average \pm standard deviation and analysed using Stata 8.0 software. All statistical treatments performed in this study show many comparisons. This procedure involves comparing pair-wise all or part of the results using Student $\mathrm{p}$ test $(\mathrm{T}>\mathrm{t})=0.05$.

\section{RESULTS AND DISCUSSION}

The results are summarized in Table 1-3.

The results show that all the vegetables grown on the three sites are contaminated with $\mathrm{Pb}, \mathrm{Cd}$ and $\mathrm{As}$, as well as their irrigation water and the soil.
The amounts reveal that for all metals the regulatory limits are over passed but the level of contamination varies from one site to another one. According to Table 1 , levels of soil pollution are significantly different for $\mathrm{Pb}$ and $\mathrm{Cd}$ at the Houeyiho site compared to the other two sites $(p<0.05)$. Normally, the use of waste to make compost at the Houeyiho site should decrease the level of lead according to (Compaore and Nanema, 2010). The proof is that the level of cadmium in the soil on this site is the lowest $(0.05 \pm 0.02 \mathrm{ppm})$. However, data about the amount of metals in the soil seem to be of less importance. Indeed, beside the case of $\mathrm{Pb}$ between Houeyiho and Aplahoue (Table 3), vegetables on the three sites have statistically the same contamination level in toxic metals ( $>0.05)$ in spite of the significant difference between the toxic metals levels in the soils. Thus, the contamination of the vegetables in toxic depended not only on the toxicity of the soils. Besides, in the watering water, levels of metals pollution are higher and significantly different for $\mathrm{Pb}, \mathrm{Cd}$ and $\mathrm{As}$ on the Godomey site compared to Houeyiho and Aplahoue sites $(\mathrm{p}<0.05)$ in spite of no-significant difference between the toxic metals levels in the vegetables. Godomey records the highest contents for the three metals: $\mathrm{Pb}$ (5.07 versus 3.39 and $2.67 \mathrm{ppm}), \mathrm{Cd}$ (1.54 versus 0.84 and $0.79 \mathrm{ppm}$ ) and As (562.6 versus 344.5 and $277.3 \mathrm{ppm}$ ). Godomey site is located on a flood plain, a swamp site having on its edge a pile of garbage of all kinds that can contain pollutants. Thus, like the case of soil, the concentration of the vegetables in a metal did not depend only on its amount in the water. However, the amount of the metal in the irrigation water at least seems to influence the contamination of the vegetables. In fact, apart the case of Godomey that has been explained above, levels of $\mathrm{Cd}$ and $\mathrm{As}$ in water at the sites of Houeyiho and Aplahoue are not significantly different as well as levels of these two metals in vegetables at these two sites. Even though it is only an insignificant quantity at the site, the bio-available level of a micro-pollutant represents all the molecules in the surrounding area and is able to contaminate the organisms (Lebourg et al., 1998). In this case, a metal found in the irrigation water represents the total quantities of metal in solution, but metals found in the vegetables are those that are rather ionized or free in the air (Tessier and Turner, 1995). For Cd and As that are ionisables and as such are bio-available to plants (Camobreco et al., 1996; Richards et al., 1998; Vulkan et al., 2002; Pitten, 1997; Gong et al., 2002), theirs concentrations in the water are close to those found in the vegetables. It's not the same with $\mathrm{Pb}$. When its concentrations in the water at the two sites are not significantly different, there is significant difference between its levels in vegetables (Table 2 and 3 ). 
Am. J. Environ. Sci., 8 (3): 248-252, 2012

Table 1: Soil contamination by toxic metals at the three sites

\begin{tabular}{|c|c|c|c|c|c|c|c|c|c|}
\hline \multirow[b]{2}{*}{ Sites } & \multicolumn{3}{|l|}{ Lead (ppm) } & \multicolumn{3}{|c|}{ Cadmium (ppm) } & \multicolumn{3}{|c|}{ Arsenic (ppm) } \\
\hline & G & $\mathrm{H}$ & $\mathrm{A}$ & $\mathrm{G}$ & $\mathrm{H}$ & A & G & $\mathrm{H}$ & A \\
\hline \multirow{7}{*}{ Samples of soils } & 9.527 & 49.75 & 4.62 & 0.74 & 0.09 & 0.63 & 151.2 & 138.79 & 112.34 \\
\hline & 9.956 & 47.92 & 4.62 & 0.81 & 0.04 & 0.72 & 165.1 & 142.58 & 107.43 \\
\hline & 11.24 & 50.72 & 5.02 & 0.74 & 0.03 & 0.56 & 158.8 & 151.33 & 115.55 \\
\hline & 10.12 & 50.20 & 5.10 & 0.83 & 0.08 & 0.93 & 162.0 & 145.94 & 104.76 \\
\hline & 9.75 & 48.51 & 4.92 & 0.75 & 0.04 & 0.89 & 160.8 & 139.84 & 92.69 \\
\hline & 10.81 & 51.67 & 4.72 & 0.77 & 0.03 & 1.10 & 153.3 & 137.91 & 92.22 \\
\hline & 9.90 & 49.10 & 4.91 & 0.64 & 0.04 & 0.68 & 163.2 & 153.34 & 115.28 \\
\hline Average \pm S D & $10.19 \pm 0.16 \mathrm{a}$ & $49.7 \pm 1.297 b$ & $4.85 \pm 019 \mathrm{a}$ & $076 \pm 0.06 \mathrm{a}$ & $0.05 \pm 0.02 b$ & $0.79 \pm 0.19 a$ & $159.2 \pm 5.16 \mathrm{a}$ & $144.25 \pm 6.16 \mathrm{a}$ & $105.75 \pm 9.89 \mathrm{a}$ \\
\hline
\end{tabular}

G, H and A are respectively the initials for Godomey, Houeyiho and Aplahoue. SD = Standard Deviation. T-test: Means for identical letter for the same metal are not significantly different; those with different letters for the same metal are significantly different. So $\mathrm{p}<0.05 \mathrm{for} \mathrm{Cd}$ and $\mathrm{Pb}$ between $\mathrm{Houeyiho}$ and the other two sites; for the rest $\mathrm{p}>0.05$. ppm is equivalent of $\mathrm{mg} / \mathrm{kg}$

Table 2: Contamination of irrigation water by toxic metals at the three sites

\begin{tabular}{|c|c|c|c|c|c|c|c|c|c|}
\hline \multirow[b]{2}{*}{ Sites } & \multicolumn{3}{|l|}{ Lead (ppm) } & \multicolumn{3}{|c|}{ Cadmium (ppm) } & \multicolumn{3}{|l|}{ Arsenic (ppm) } \\
\hline & G & $\mathrm{H}$ & $\mathrm{A}$ & G & $\mathrm{H}$ & A & G & $\mathrm{H}$ & A \\
\hline \multirow{7}{*}{ Samples of water } & 4.81 & 2.85 & 2.24 & 1.65 & 0.79 & 0.92 & 583.11 & 335.41 & 281.02 \\
\hline & 5.07 & 3.51 & 3.10 & 1.45 & 0.82 & 0.62 & 592.82 & 344.52 & 280.51 \\
\hline & 3.97 & 3.52 & 2.09 & 1.43 & 0.79 & 0.74 & 571.81 & 353.12 & 269.61 \\
\hline & 4.96 & 3.45 & 2.51 & 1.16 & 0.92 & 0.90 & 542.51 & 343.94 & 282.41 \\
\hline & 5.41 & 3.52 & 3.50 & 1.80 & 0.72 & 0.83 & 502.41 & 342.14 & 265.71 \\
\hline & 5.71 & 3.54 & 2.81 & 1.62 & 0.83 & 0.65 & 573.71 & 336.54 & 275.91 \\
\hline & 5.54 & 3.35 & 2.41 & 1.63 & 0.99 & 0.85 & 572.93 & 356.13 & 285.90 \\
\hline Average \pm S D & $5.07 \pm 0.58 \mathrm{~b}$ & $3.39 \pm 0.24 \mathrm{a}$ & $2.67 \pm 0.50 \mathrm{a}$ & $1.54 \pm 0.20 \mathrm{~b}$ & $0.84 \pm 0.09 \mathrm{a}$ & $0.79 \pm 0.11 \mathrm{a}$ & $562.6 \pm 30.75 b$ & $344.54 \pm 7.76 \mathrm{a}$ & $277.3 \pm 7.29 \mathrm{a}$ \\
\hline
\end{tabular}

T-test: The values for identical letters, for the same metal are not significantly different; those with different letters for the same metal are significantly different. $\mathrm{p}<0.05$ for $\mathrm{Pb}, \mathrm{Cb}$ and As between Godomey and each of the other two sites; for the rest $\mathrm{p}>0.05$

Table 3: Contamination of vegetables by toxic metals at the three sites

\begin{tabular}{|c|c|c|c|c|c|c|c|c|c|}
\hline \multirow[b]{2}{*}{ Sites } & \multicolumn{3}{|l|}{ Lead (ppm) } & \multicolumn{3}{|c|}{ Cadmium (ppm) } & \multicolumn{3}{|c|}{ Arsenic (ppm) } \\
\hline & G & $\mathrm{H}$ & A & $\mathrm{G}$ & $\mathrm{H}$ & A & $\mathrm{G}$ & $\mathrm{H}$ & A \\
\hline L. sativa & 4.84 & 3.10 & 6.03 & 0.89 & 0.63 & 0.07 & 237.62 & 260.48 & 315.13 \\
\hline A. hybridus & 5.01 & 3.73 & 5.92 & 0.93 & 5.13 & 0.32 & 171.63 & 259.92 & 302.15 \\
\hline S. macrocarpum & 2.52 & 3.38 & 5.99 & 0.82 & 0.64 & 0.81 & 282.73 & 316.28 & 219.19 \\
\hline B. oleracea & 6.69 & 3.12 & 6.32 & 1.73 & 0.55 & 0.79 & 230.81 & 325.30 & 195.08 \\
\hline D. carota & 1.06 & 1.14 & 2.37 & 1.22 & 0.72 & 0.53 & 300.51 & 251.45 & 270.18 \\
\hline C. olitorius & 3.5 & 4.76 & 5.52 & 0.91 & 1.17 & 1.10 & 271.76 & 241.41 & 255.12 \\
\hline A. сера & 2.85 & 3.36 & 4.80 & 0.43 & 0.26 & 0.34 & 358.67 & 323.52 & 196.40 \\
\hline S. oleracea & 4.08 & 3.46 & 4.95 & 0.34 & 0.52 & 0.75 & 231.84 & 204.01 & 232.02 \\
\hline Average \pm S D & $3.82 \pm 1.73$ & $3.26 \pm 1.0 \mathrm{a}$ & $5.24 \pm .88 \mathrm{~b}$ & $0.91 \pm 0.43$ & $1.20 \pm 1.60$ & $0.59 \pm 0.33$ & $260.7 \pm 56.04$ & $272.8 \pm 44.25$ & $248.16 \pm 45.56$ \\
\hline
\end{tabular}

T-test: values followed by letters are significantly different; others are not for the same metal. $\mathrm{P}<0.05$ for Pb between Houeyiho and Aplahoue (they are significantly different for the $\mathrm{Pb}$ ), for the rest $\mathrm{p}>0.05$

This is the case of the Houeyiho and Aplahoue sites. In the contrary, when concentrations of lead in the water at two sites are significantly different, there is not significant difference between their levels in the vegetables. This is the cases between Godomey and Houeyiho or Godomey and Aplahoue. Everything happens like the levels of lead found in the vegetables are not linked to the irrigation water. Normally, there should not be higher level of lead in vegetables (Ross, 1994) because it is not ionized (Ablain, 2002). However, according Table $3, \mathrm{~Pb}$ is abundantly found in the vegetables; it means that it should be from various sources. Some authors (Pietel et al., 2000) thought that the $\mathrm{Pb}$ found in the vegetables is mostly atmospheric. Then the vegetables-leave would have been exposed than those without leave. Such hypothesis is proved by the results. Indeed, levels in lead of Daucus carota and Allium cepa that are no-leave vegetables, respectively being among the low-level group (1.06 and 2.85 versus average $3.82 \mathrm{ppm}$ at Godomey site; 1.14 and 3.36 versus average $3.26 \mathrm{ppm}$ at Houeyiho site; 2.37 and 4.80 versus $5.24 \mathrm{ppm}$ at Aplahoue site). Therefore if the contamination by cadmium and arsenic in the watering water seems to be much closer to that of vegetables, it is because the metals are ionized in water which determinate theirs bio-availability. So, the contamination of vegetables does not depend on the toxics levels in the soil neither in the watering water but to bio-availability of metal (Xian, 1989). Studies have highlighted some other factors involved in the bioaccumulation of toxic metals by organisms, such as: the speciation of the metal, the intrinsic nature of the 
organism and the biotic, physic and chemical factors according to (Tessier and Turner, 1995). Finally, the overall results help to notice that high urban and atmospheric pressures in Cotonou where the Godomey and Houeyiho sites are located, have significantly influenced the contamination in toxic metals of the soils, the irrigation water and the vegetables when we compare the results from these sites to those of the site in Aplahoue, a rural area. For, it is in Aplahoue, farming environment, that the lowest amounts of $\mathrm{Pb}, \mathrm{Cd}$ and As in water (2.67, 0.79 and $277.3 \mathrm{ppm})$; the lowest levels of $\mathrm{Pb}$ and $\mathrm{As}$ (4.85 and $105.75 \mathrm{ppm}$ ) in soil and the lowest amounts of $\mathrm{Cd}$ and As (0.59 and 248.16 $\mathrm{ppm})$ in the vegetables have been recorded. The heavy vehicle traffic near the gardening sites in the city of Cotonou, the use of adulterated oil, the proximity of garbage dumps and the presence in great number of craftsmen stalls which are toxic metals contamination sources explain these results.

\section{CONCLUSION}

Surface waters are an important resource in agriculture. Unfortunately, the one used on some gardening sites of Benin is contaminated by toxic metals from the air or soil. The results of this study revealed that when the soil is contaminated, so is the water in the soil and the vegetables or plants that grow there. It is difficult to clearly establish the link between contaminated soil, water and the sanitary quality of grown vegetables. But the study has helped to understand that the pollution of the market products has no borders. Thus, there is a risk of contamination in the food chain by heavy metals whose consumption through these gardening products could cause public health problems. Thus, the adoption of reasonable behaviour and the development of new technologies are needed to associate food security, economic development, the preservation of the environment and public health.

\section{REFERENCES}

Ablain, F., 2002. Rôle des activités lombriciennes sur la redistribution des éléments traces métalliques issus de boue de station d'épuration dans un sol agricole. Universite De Rennes.

Anane, R., M. Bonini, M.J. Grafeille and E.E. Creppy, 1995. Bioaccumulation of water soluble aluminium chloride in the hippocampus after transdermal uptake in mice. Arch. Toxicol., 69: 568-571. PMID: 8534202
Assogba, F. and V. Miguel, 1999. Agriculture Urbaine et Periurbaine à Cotonou. 1st Edn., Bulletin de la Recherche Agronomique, pp: 27.

Camobreco, V.J., B.K. Richards, T.S. Steenhuis, J.H. Peverly and M.B. McBride, 1996. Movement of heavy metals through undisturbed and homogenized soil columns. Soil Sci., 161: 740-750.

Compaore, E. and L.S. Nanema, 2010. Compostage et qualite du compost de dechets urbains solides de la ville de bobo-dioulasso, burkina faso. Tropicultura, 28: 232-237.

Gnandi, K., K. Tozo, A.P. Edorh, H. Abi and K. Agbeko et al., 2008. Bioaccumulation of some metallic elements in the Produce grown on urban soils along the highway-Aneho Lome, Togo South. Acta Bot. Gallica, 155: 415-426.

Gong, S., X.W. Yang, C. Li and N. Heintz, 2002. Highly efficient modification of Bacterial Artificial Chromosomes (BACs) using novel shuttle vectors containing the R6K $\gamma$ origin of replication. Genome Res., 12: 1992-1998. DOI: 10.1101/gr.476202

Lebourg, A., T. Sterckeman, H. Ciesielski and N. Proix, 1998. Trace metal speciation in three unbuffered salt solutions used to assess their bioavailability in soil. J. Environ. Q., 27: 584-590.

Mougeot, L.J.A., 2000. Urban agriculture: Definition, Presence, Potentials and Risks. In: Growing Cities, Growing Food, Urban Agriculture on the Policy Agenda, Bakker, N., M. Dubbeling, S. Guendel, U.S. Koschella and H.D. Zeeuw (Eds.). DSE, Feldafing, pp: 99-117.

Pietel, J., K. Kuroiwa and H.T. Sawyerr, 2000. Distribution of $\mathrm{Pb}, \mathrm{Cd}$ and $\mathrm{Ba}$ in soils and plants of two contamined soils. Environ. Pollut., 110: 171178. DOI: 10.1016/S0269-7491(99)00272-9

Pitten, F.A., 1997. Arsenakkumulation in Pflanzen: Abschlußbericht. Greifswald.

Richards, B.K., T.S. Steenhuis, J.H. Peverly and M.B. McBride, 1998. Metal mobility at an old, heavily loaded sludge application site. Environ. Pollut., 99: 365-377. DOI: 10.1016/S0269-7491(98)00011-6

Ross, S.M., 1994. Toxic Metals in Soil-Plant Systems. 1st Edn., John Wiley and Sons, Chichester, ISBN: 0471942790, pp: 469.

Tessier, A. and D.R. Turner, 1995. Metal Speciation and Bioavailability in Aquatic Systems. 1st Edn., John Wiley and Sons, Chichester, ISBN: 0471958301, pp: 679.

Vaidya, C.O. and R.T.T. Rantala, 1996. A comparative study of analytical methods: Determination of heavy metals in mussels (Mytilus edulis) from Eastern Canada. Int. Environ. Anal. Chem., 63: 179-185. DOI: $10.1080 / 03067319608026264$ 
Vulkan, R., U. Mingelgrin, J. Ben-Asher and H. Frenkel, 2002. Copper and zinc speciation in the solution of a soil-sludge mixture. J. Environ. Q., 31: 193-203. DOI: $10.2134 /$ jeq2002.1930
Xian, X., 1989. Effect of chemical forms of cadmium, zinc and lead in polluted soils on their uptake by cabbage plants. Plant Soil, 113: 257-264. DOI: 10.1007/BF02280189 